\title{
Effect of Tyrosin Kinase Inhibitors on NK Cell and ILC3 Development and Function
}

\author{
Laura Damele ${ }^{1,2}$, Elisa Montaldo ${ }^{3 t}$, Lorenzo Moretta ${ }^{4}$, Chiara Vitale ${ }^{1,5 * \neq}$ and \\ Maria Cristina Mingari ${ }^{1,2,5 \neq}$
}

${ }^{1}$ Dipartimento Medicina Sperimentale, Università degli Studi di Genova, Genova, Italy, ${ }^{2}$ Centre of Excellence for Biomedical Research, Università degli Studi di Genova, Genova, Italy, ${ }^{3}$ IRCCS G. Gaslini, Genova, Italy, ${ }^{4}$ Immunology Area Lab, Pediatric Hospital Bambino Gesù, Rome, Italy, ${ }^{5}$ UO Immunologia, IRCCS Ospedale Policlinico San Martino, Genova, Italy

\section{OPEN ACCESS}

Edited by:

Nicholas D. Huntington, Walter and Eliza Hall Institute of Medical Research, Australia

Reviewed by:

Rafael Solana,

Universidad de Córdoba, Spain Jacques Zimmer

Luxembourg Institute of Health $(L I H)$,

Luxembourg

*Correspondence: Chiara Vitale

chiara.vitale@unige.it

${ }^{\dagger}$ Present Address

Elisa Montaldo,

Genomic of the Innate Immune System Lab. San Raffaele Telethon Institute for Gene Therapy, IRCCSSan Raffaele Scientific Institute, Milan,

‡Joint senior authorship

Specialty section:

This article was submitted to NK and Innate Lymphoid Cell Biology, a section of the journal

Frontiers in Immunology

Received: 06 July 2018 Accepted: 02 October 2018 Published: 23 October 2018

Citation:

Damele L, Montaldo E, Moretta L, Vitale $C$ and Mingari MC (2018) Effect of Tyrosin Kinase Inhibitors on NK Cell and ILC3 Development and Function.

Front. Immunol. 9:2433. doi: 10.3389/fimmu.2018.02433
Tyrosin kinase inhibitors (TKI) sharply improved the prognosis of Chronic Myeloid Leukemia (CML) and of Philadelphia ${ }^{+}$Acute Lymphoblastic Leukemia ( $\left.\mathrm{Ph}^{+} \mathrm{ALL}\right)$ patients. However, TKI are not curative because of the development of resistance and lack of complete molecular remission in the majority of patients. Clinical evidences would support the notion that patient's immune system may play a key role in preventing relapses. In particular, increased proportions of terminally differentiated $\mathrm{CD}_{56}{ }^{+} \mathrm{CD} 16^{+} \mathrm{CD} 57^{+} \mathrm{NK}$ cells have been reported to be associated with successful Imatinib therapy discontinuation or with a deep molecular response in Dasatinib-treated patients. In view of the potential role of NK cells in immune-response against CML, it is important to study whether any TKI have an effect on the NK cell development and identify possible molecular mechanism(s) by which continuous exposure to in vitro TKI may influence NK cell development and repertoire. To this end, $\mathrm{CD}_{4}{ }^{+}$hematopoietic stem cells (HSC) were cultured in the absence or in the presence of Imatinib, Nilotinib, or Dasatinib. We show that all compounds exert an inhibitory effect on $\mathrm{CD} 56^{+}$cell recovery. In addition, Dasatinib sharply skewed the repertoire of $\mathrm{CD}^{+} 6^{+}$cell population, leading to an impaired recovery

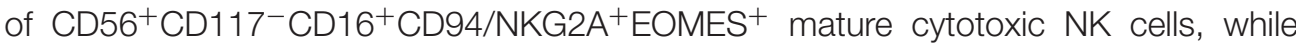
the recovery of $\mathrm{CD}_{56}{ }^{+} \mathrm{CD} 117^{+} \mathrm{CD} 94 / \mathrm{NKG} 2 \mathrm{~A}^{-} \mathrm{ROR} \gamma \mathrm{t}^{+}$IL-22-producing ILC3 was not affected. This effect appears to involve the Dasatinib-mediated inhibition of Src kinases and, indirectly, of STAT5-signaling activation in CD34+ cells during first days of culture. Our studies, reveal a possible mechanism by which Dasatinib may interfere with the proliferation and maturation of fully competent NK cells, i.e., by targeting signaling pathways required for differentiation and survival of NK cells but not of ILC3.

Keywords: innate lymphocyte cells, NK cell development, tyrosin kinase inhibitors, CML-chronic myelogenous leukemia, ILC3

\section{INTRODUCTION}

Therapy with tyrosin kinase inhibitors (TKI) has greatly improved the prognosis of Chronic Myeloid Leukemia (CML) and of Philadelphia ${ }^{+}$Acute Lymphoblastic Leukemia $\left(\mathrm{Ph}^{+} \mathrm{ALL}\right)$ patients (1-3). However, despite their efficacy, TKI cannot be considered as curative therapeutic agents, because the majority of patients develop resistance or lack complete molecular remission 
(4-6). Moreover, patients undergoing life-long treatment may experience adverse effects that compromise their quality of life $(6-8)$. Thus, during the past several years, the achievement of therapy discontinuation, allowing long treatment-free remissions (TFR) became a main area of investigation (8). Recent clinical trials indicated that $\sim 40 \%$ of patients with deep molecular response (DMR), who undergo therapy discontinuation, remain free of relapse for several years (8-10). Clinical evidences would support the notion that the patient's immune system may play a key role either by eradicating leukemia or by exerting a successful long-lasting control of residual leukemic cells. Indeed, patients with an efficient effector arm of their immune system display a significantly longer TFR with a DMR (11-13). Thus, ongoing major efforts are aimed to identify immune mechanisms and biomarkers that may help to select patients who are suitable for successful therapy discontinuation upon achievement of a DMR. In this context, analysis of natural killer (NK) cells, capable of a potent anti-leukemia activity, could offer a clue to identify such patients (14).

NK cells represent an important component of the innate immunity. Their function is finely tuned by inhibitory and activating receptors. Remarkably, NK cells have been shown to play an important role in the favorable clinical outcome of patients with high risk leukemias undergoing haploidentical Hematopoietic Stem Cell Transplant (15-18). NK cells can recognize and kill leukemic blasts, particularly those displaying down-regulation of HLA-class I molecules (failing to interact with HLA-specific inhibitory NK receptors such as KIR and CD94/NKG2A), and/or over-expressing ligands recognized by activating NK receptors (including Natural Cytotoxic Receptors, NCR, NKG2D and DNAM-1) $(16,19)$. Certain activating KIR, present only in some individuals, may also positively contribute to the anti-leukemia activity $(14,20,21)$.

NK cell development occurs primarily in the bone marrow (BM), requires the expression of E4BP4 (NFIL3), Tbx21 (T-bet), eomesodermin (EOMES) transcription factors (TF), and proceeds through a multi-step process, characterized by the sequential acquisition of surface receptor markers (including CD161, CD56, CD94/NKG2A, LFA-1, CD16, KIRs, and CD57) and given functional capabilities (22-24). NK cells are developmentally related to Innate Lymphoid Cells (ILCs) as they derive from a common DNA-binding protein inhibitor (ID2)-positive hematopoietic precursor (24). Members of ILC family are thought to play a relevant role in innate defenses against pathogens, in epithelial tissue homeostasis and in lymphoid structure organization. Three main groups of ILCs have been identified: ILC1, ILC2, and ILC3, on the basis of their cytokine profile and transcription factors (TF) required for their differentiation (25). In vitro models of human NK cell development from umbilical cord blood (UCB)-derived $\mathrm{CD}_{3}{ }^{+}$cells revealed that these precursors can give rise both to NK cells and ILC3. The expression of CD94/NKG2A and LFA-1 marks CD $161^{+} \mathrm{CD} 6^{+} \mathrm{CD} 117^{-} \mathrm{CD} 7^{+}$ NK cells that express NCR, cytolytic granules and production of IFN- $\gamma$. On the other hand, the lack of expression of CD94/NKG2A and LFA-1 (CD161 ${ }^{+} \mathrm{CD} 56^{+} \mathrm{CD} 117^{+} \mathrm{CD} 7{ }^{-} \mathrm{LFA}^{-}$ $1^{-}$CD94/NKG2A ${ }^{-}$) identifies a heterogeneous cell subset, that may contain both NK cell precursors and ILC3, characterized by the expression of RAR-related orphan receptor gamma $(\mathrm{ROR} \gamma \mathrm{t}) \mathrm{TF}$ and by the ability to produce IL-22 (26, 27).

In the past few years, the effects of TKI on the NK cell repertoire and function have been analyzed in several studies (28). Of note, increased proportions of terminally differentiated cytolytic $\mathrm{CD} 56^{+} \mathrm{CD} 16^{+} \mathrm{CD} 57^{+} \mathrm{NK}$ cells were found in patients that achieved a successful Imatinib therapy discontinuation or in Dasatinib-treated patients with a DMR (12, 29-32). Recently, it has also been suggested that KIR genotype may represent a new biomarker for response to TKI therapy (33-35). On the other hand, previous in vitro studies reported conflicting results on the effect of different TKI on NK cell proliferation and function (28).

In view of the potential role of NK cells in the control of CML, it is important to study the effect of TKI not only on mature NK cells, but also on NK cells undergoing maturation. Notably, TKI may impair hematopoiesis, consequent to the inhibitory effect on c-KIT transduction pathway. Moreover, Dasatinib inhibits Src kinase, also involved in the regulation of hematopoiesis. Thus, it is possible that prolonged administration of TKI may affect NK cell differentiation from Hematopoietic Stem Cells (HSC) (24, 36-38). To explore this possibility, whether indeed TKI could influence NK cell development and repertoire, UCB-derived CD34 ${ }^{+}$HSC were cultured in the absence or in the presence of Imatinib, Nilotinib, or Dasatinib. Our results show that all compounds exert an inhibitory effect on cell proliferation. In addition, Dasatinib sharply skewed the repertoire of $\mathrm{CD}^{2} 6^{+}$cells, with an impaired recovery of $\mathrm{CD}^{2} 6^{+} \mathrm{CD} 117^{-} \mathrm{CD} 16^{+} \mathrm{CD} 94 / \mathrm{NKG}^{+} \mathrm{A}^{+}$EOMES $^{+}$ mature cytotoxic NK cells, paralleled by an enrichment of $\mathrm{CD}_{56}{ }^{+} \mathrm{CD} 117^{+} \mathrm{CD} 94 / \mathrm{NKG} 2 \mathrm{~A}^{-} \mathrm{ROR} \gamma \mathrm{t}^{+}$ILC3. This effect appears to involve the Dasatinib-mediated inhibition of Src kinases. Our studies, revealed a mechanism by which Dasatinib may interfere with the maturation of fully competent NK cells, i.e., by targeting signaling pathways required for differentiation of NK cells but not of ILC3.

\section{MATERIALS AND METHODS}

\section{Cell Isolation and in vitro Culture}

Liguria Cord Blood Bank provided UCB samples from healthy individuals. Ethical Committee approved the study and mothers gave their written informed consent according to the Helsinki Declaration. Mononuclear cells were obtained by Ficoll-Lympholyte (Cedarlane, Canada) separation. CD56 ${ }^{-} \mathrm{CD} 34^{+}$cells (>98\% purity) were obtained by MACS positive separation (Miltenyi Biotec, Germany). Cells were cultured in RPMI 1640 (Lonza, Belgium) containing 10\% human AB serum (Biowest, France), Stem Cell Factor (SCF) $(10 \mathrm{ng} / \mathrm{ml})$, Fms-related tyrosine kinase 3 ligand (FLT3-L) $(10 \mathrm{ng} / \mathrm{ml})$, Interleukin-7 (IL-7) $\quad(20 \mathrm{ng} / \mathrm{ml})$, Interleukin-15 (IL-15) $(20 \mathrm{ng} / \mathrm{ml})$, Interleukin-21 (IL-21) $(20 \mathrm{ng} / \mathrm{ml})$ (Miltenyi Biotec,), in the absence or in the presence of: Imatinib (IM $5 \mu \mathrm{M}$ ), Nilotinib (NIL 3, $6 \mu \mathrm{M}$ ), Dasatinib (DAS $200 \mathrm{nM}$ ) (Selleck Chemicals, USA) at the plasma concentration $30 \mathrm{~min}$ post administration, or with Dimethyl sulfoxide (DMSO) at the 
corresponding concentration of the drugs (D 1:1,000/1:25,000) (Sigma-Aldrich, USA) or with KX2-391 used at different concentrations (Selleck Chemicals). We added TKI, DMSO, or KX2-391 at day 0 and at later intervals i.e., $24 \mathrm{~h}, 4,10$, or 15 days.

\section{Monoclonal Antibodies (mAbs) and Flow Cytometry}

mAbs were purchased from several companies. A full list of the mAbs utilized is provided in Table 1. All the mAbs were mouseanti human, with the exception of ROR- $\gamma \mathrm{t}$ mAb, Phospho-Stat3 (Tyr705)(D3A7)XP mAb, and Phospho-Stat5 (Tyr694)(D47E7) $\mathrm{XP} \mathrm{mAb}$ were from Rabbit. To perform cell gating strategy we first identified morphological parameters using FSC-A vs. SSC-A. Then, we performed a further gate in which we analyze the FSC-A vs. FSC-H, in order to limit any interference due to doublets. To assess cell viability we performed analyses with Propidium Iodide and Annexin V.

\section{Cell Cytotoxicity Assay}

Cell cytotoxicity was analyzed in a $4 \mathrm{~h} 51 \mathrm{Cr}$-release assay against human leukemic K562 cell line. Cells were counted, washed and plated. Effector/Target $(\mathrm{E} / \mathrm{T})$ cell ratio is $2 / 1$. The effector target ratio was normalized to the numbers of $\mathrm{CD}^{+} 6^{+}$cells present in each culturing conditions. To this end, we adjusted the number of effector cells in each condition accordingly to the $\mathrm{CD}_{56}{ }^{+}$cells present in the cultures and to the cell count performed simultaneously by using MACSQuant flowcytometer. Experiments were performed in duplicates. Data are expressed as percentage of target cell lysis.

\section{Intra-cytoplasmic Cytokine, Cytolytic Granules, and TF Expression Assays}

To detect cytokines, cells cultured in different conditions, were washed, suspended and over night stimulated with IL$12(10 \mathrm{ng} / \mathrm{ml})$, IL-15 $(50 \mathrm{ng} / \mathrm{ml})$, IL-18 $(100 \mathrm{ng} / \mathrm{ml})$, or IL$1 \beta(50 \mathrm{ng} / \mathrm{ml}), \mathrm{IL}-7(50 \mathrm{ng} / \mathrm{ml}), \mathrm{IL}-23(50 \mathrm{ng} / \mathrm{ml})$ (Peprotech, $\mathrm{UK}$ ) in the presence of monensin (GolgiStop) or brefeldin (GolgiPlug) (Biosciences), respectively. For intra-cytoplasmic cytokine and cytolytic granules analyses, cells were stained for surface markers and then fixed and permeabilized with Fixation and Permeabilization Kit (BD Biosciences, New Jersey USA). Then, cells were incubated with cytokine- or Perforinspecific mAb. To detect TF expression, cells were suspended in 5\% BSA buffer, stained for surface markers, subsequently fixed with Transcription Factor Staining Buffer Set (eBioscienceThermoFisher) and stained for ROR $\gamma \mathrm{t}$, and EOMES TF; instead, to detect expression of pSTAT3 and pSTAT5, cells were fixed with PFA $4 \%$ and methanol $100 \%$ and after that cells were stained with anti-pSTAT antibodies.

\section{Statistical Analysis}

Prism GraphPad software was used for statistical analysis. We considered significant $P \leq 0.05$.
TABLE 1 | List of the mAbs used in the experiments.

\begin{tabular}{|c|c|c|c|}
\hline Antigen & $\begin{array}{l}\text { Antibody } \\
\text { clone }\end{array}$ & Fluorochrome & Supplier \\
\hline CD56 & N901 & PeCy7 & Beckman-Coulter \\
\hline CD159a & Z199 & APC & Beckman-Coulter \\
\hline CD159a & Z199 & $\mathrm{PE}$ & Beckman-Coulter \\
\hline CD158a & EB6B & APC & Beckman-Coulter \\
\hline CD158b1,b2 & GL183 & APC & Beckman-Coulter \\
\hline CD158e1,e2 & Z27.3.7 & APC & Beckman-Coulter \\
\hline CD158a & EB6B & $\mathrm{PE}$ & Beckman-Coulter \\
\hline CD158b1,b2 & GL183 & $\mathrm{PE}$ & Beckman-Coulter \\
\hline CD158e1,e2 & Z27.3.7 & $\mathrm{PE}$ & Beckman-Coulter \\
\hline CD336 (NKp44) & Z231 & $\mathrm{PE}$ & Beckman-Coulter \\
\hline CD337 (NKp30) & $\mathrm{Z} 25$ & $\mathrm{PE}$ & Beckman-Coulter \\
\hline CD335 (NKp46) & BAB281 & $\mathrm{PE}$ & Beckman-Coulter \\
\hline CD33 & AC104.3E3 & APC & Miltenyi Biotec \\
\hline CD14 & TÜK4 & FITC & Miltenyi Biotec \\
\hline HLA-DR & AC122 & PerCP & Miltenyi Biotec \\
\hline CD16 & REA423 & FITC & Miltenyi Biotec \\
\hline CD11a (LFA-1) & $\mathrm{TS} 2 / 4$ & PerCP & BioLegend \\
\hline CD11a (LFA-1) & $\mathrm{TS} 2 / 4$ & FITC & BioLegend \\
\hline CD7 & CD7-6B7 & FITC & BioLegend \\
\hline CD335 (NKp46) & 9E2 & eFluor450 & BioLegend \\
\hline CD117 (c-KIT) & 104D2 & PerCP-Cy5.5 & BioLegend \\
\hline CD161 & HP-3G10 & PerCP-Cy5.5 & BioLegend \\
\hline CD226 (DNAM-1) & $11 \mathrm{~A} 8$ & $\mathrm{PE}$ & BioLegend \\
\hline CD94 & DX22 & FITC & BioLegend \\
\hline CD336 (NKp44) & P44-8 & AF-647 & BioLegend \\
\hline CD337 (NKp30) & P30-15 & AF-647 & BioLegend \\
\hline CD16 & $3 G 8$ & BV-421 & BioLegend \\
\hline CD127 & A019D5 & BV-421 & BioLegend \\
\hline CD132 & TUGh4 & APC & Biolegend \\
\hline CD14 & 61D3 & eFluor450 & $\begin{array}{l}\text { eBioscience- } \\
\text { ThermoFisher }\end{array}$ \\
\hline CD117 & 104D2 & $B V-421$ & $\begin{array}{l}\text { eBioscience- } \\
\text { ThermoFisher }\end{array}$ \\
\hline CD14 & 61D3 & APC-eFluor-780 & $\begin{array}{l}\text { eBioscience- } \\
\text { ThermoFisher }\end{array}$ \\
\hline IL-22 & 22URTI & PE & $\begin{array}{l}\text { eBioscience- } \\
\text { ThermoFisher }\end{array}$ \\
\hline $\mathrm{ROR}-\gamma \mathrm{t}$ & AFKJS-9 & $\mathrm{PE}$ & $\begin{array}{l}\text { eBioscience- } \\
\text { ThermoFisher }\end{array}$ \\
\hline EOMES & WD1928 & eFluor-660 & $\begin{array}{l}\text { eBioscience- } \\
\text { ThermoFisher }\end{array}$ \\
\hline Perforin & dG9 & $\mathrm{PE}$ & $\begin{array}{l}\text { eBioscience- } \\
\text { ThermoFisher }\end{array}$ \\
\hline $\mathrm{IFN}-\gamma$ & 4S.B3 & eFluor450 & $\begin{array}{l}\text { eBioscience- } \\
\text { ThermoFisher }\end{array}$ \\
\hline TNF- $\alpha$ & MAb11 & eFluor450 & $\begin{array}{l}\text { eBioscience- } \\
\text { ThermoFisher }\end{array}$ \\
\hline CXCL8 & 6217 & $\mathrm{PE}$ & $R \& D$ system \\
\hline $\begin{array}{l}\text { pSTAT3 XP rabbit } \\
\text { (Tyr705) }\end{array}$ & D3A7 & Unconjugated & Cell signaling \\
\hline $\begin{array}{l}\text { pSTAT5 XP rabbit } \\
\text { (Tyr694) }\end{array}$ & D47E7 & Unconjugated & Cell signaling \\
\hline $\begin{array}{l}\text { Goat-anti rabbit } \\
(\operatorname{lgG} \mathrm{H}+\mathrm{L}) \operatorname{lgG} 1\end{array}$ & A27034 & AF-488 & $\begin{array}{l}\text { Invitrogen- } \\
\text { ThermoFisher }\end{array}$ \\
\hline CD122 & Mik- $\beta 2$ & $\mathrm{PE}$ & BD Pharmingen \\
\hline
\end{tabular}




\section{RESULTS}

\section{TKI Inhibit in vitro Proliferation of Myeloid and Lymphoid Precursors From CD34 ${ }^{+}$ HSC}

In order to analyze the effects of different TKI on in vitro NK cell differentiation, UCB-CD $34^{+}$HSC were isolated and cultured with cytokines (SCF, FLT3-1, IL-7, IL-15 and IL-21, see section Material and Methods), suitable to promote NK cell differentiation, either in the absence (control $=$ CTR) or in the presence of different TKI at plasmatic concentrations: Imatinib $5 \mu \mathrm{M}$ (IM), Nilotinib $3.6 \mu \mathrm{M}$ (NIL), Dasatinib $0.2 \mu \mathrm{M}$ (DAS). DMSO was used as vehicle control. After 15 days of culture, cells were counted and analyzed for informative surface markers. As shown in Figure 1A, TKI led to a decreased mono-nucleated cell recovery that was particularly sharp in the case of Dasatinib. Evaluation of the surface staining for Annexin $\mathrm{V}$ after 3 and 8 days of culture suggested that the strong reduction of cell numbers detected in the presence of Dasatinib may be due to an increased programmed cell death, occurring during the first week of culture (Figure 1B). The analysis of informative cell surface markers indicated that the recovery of both $\mathrm{CD} 33^{+} \mathrm{CD} 14^{-}$myeloid cells and $\mathrm{CD} 33^{+} \mathrm{CD} 14^{+}$ monocytes, was sharply reduced in the presence of all TKI analyzed (Figure 1C). Remarkably, all TKI induced a significant reduction of $\mathrm{CD} 161^{+} \mathrm{CD} 56^{+}$absolute cell numbers as compared to controls. Also in this case, the effect was most striking in the presence of Dasatinib (Figure 1D). Of note, results obtained in cultures performed in the presence of Dasatinib displayed a sharp significant difference also with cultures performed in the presence of DMSO 1:25,000 (Figures 1A,C,D). Since cultures performed with DMSO at the final concentrations of 1:25,000 did not substantially differ in cell recovery from the CTR cultures, data on the cultures performed with DMSO at this concentration will not be shown any further.

\section{Dasatinib Skews in vitro Cell Differentiation of CD161 ${ }^{+}$CD56 $^{+}$Precursors Toward ILC3}

Next, we analyzed the surface phenotype of $\mathrm{CD} 161^{+} \mathrm{CD} 56^{+}$ cells obtained after 25 days under the culture conditions indicated above. As shown in Figure 2A, analysis of the receptor repertoire of $\mathrm{CD}^{2} 6^{+}$cells revealed a significant reduction of $\mathrm{CD} 56^{+} \mathrm{CD} 94 / \mathrm{NKG} 2 \mathrm{~A}^{+}$cells in the presence of Dasatinib, while the percentages of $\mathrm{CD} 56^{+} \mathrm{CD} 117^{+}$cells were significantly increased. Accordingly, also the percentages of $\mathrm{NKG}_{2} \mathrm{D}^{+}$, $\mathrm{DNAM}-1^{+}$, and $\mathrm{CD}^{+} 6^{+}$cells were reduced as compared to controls (Figure 2B). Figure 2C shows a representative experiment: in the presence of Dasatinib, a major decrease of percentages of $\mathrm{CD}^{+} 6^{+}$cells could be detected. Moreover, the majority of $\mathrm{CD}_{6} 6^{+}$cells were represented by $\mathrm{CD} 117^{+} \mathrm{LFA}-$ $1^{-} \mathrm{CD} 94 / \mathrm{NKG}_{2} \mathrm{~A}^{-} \mathrm{CD} 16^{-}$cells, a subset that may include both ILC3 and Stage III NK cell precursors (27). Thus, we further analyzed the expression of ROR $\gamma \mathrm{t}$ and Eomes TF, which allows discriminating ILC3 and stage IV/V NK cells. This analysis revealed a significant increase of $\mathrm{CD} 56^{+} \mathrm{ROR} \gamma \mathrm{t}^{+}$ ILC3 and a significant decrease of CD56 ${ }^{+}$Eomes $^{+}$NK cells as compared to controls (Figures 3A,B), Of note, we could detect higher percentages of $\mathrm{CD} 6^{+} \mathrm{CD} 117^{+} \mathrm{CD} 127^{+}\left(\mathrm{CD} 132^{+}\right)$cells in cultures performed in the presence of Dasatinib as compared to controls, while $\mathrm{CD} 122^{+}$cells were virtually undetectable (Figure 3C).

\section{CD161 ${ }^{+}$CD56 ${ }^{+}$Cells Developed in the Presence of Dasatinib Express Higher Percentages of IFN $-\gamma^{+}$Cells but Display a Reduced Cytolytic Activity}

The altered composition of $\mathrm{CD} 6^{+}$cell subsets occurring in the presence of Dasatinib, suggests that this compound may affect NK cell differentiation and proliferation. To verify whether TKI could also affect the functional activity of $\mathrm{CD} 56^{+}$cells, we analyzed the intra-cytoplasmic cytokine expression and the cytolytic activity against the NK-susceptible K562 human leukemia cell line.

$\mathrm{CD}^{+} 6^{+}$lymphoid cells, developed in the absence or in the presence of different TKI, were stimulated either with IL-1 $\beta$, IL-7, and IL-23, or with IL-12, IL-15, and IL-18 and analyzed for intra-cytoplasmic cytokine expression by flow cytometry. Figures $4 \mathrm{~A}, \mathrm{~B}$ shows that $\mathrm{CD} 56^{+} \mathrm{CD} 117^{+} \mathrm{CD} 94^{-}$ ILC3 subset, generated in the presence of Dasatinib, display higher percentages of IL- $22^{+}$and IL- $8^{+}$cells and a slight increase of IFN $-\gamma^{+}$cells. Interestingly, in the presence of Dasatinib, also the small $\mathrm{CD} 56^{+} \mathrm{CD} 117^{-/+} \mathrm{CD} 94^{+}$cell subset, expressed higher proportions of IFN- $\gamma^{+}$cells as compared to the other culturing conditions (Figures 4A,B). Analysis of the cytolytic activity against $\mathrm{K} 562$ target cells, indicated that $\mathrm{CD} 56^{+}$cells generated in the presence of Nilotinib or Dasatinib, were significantly less cytolytic (Figure 4C). Of note, the decreased cytotoxicity, observed in the presence of Dasatinib, was associated to lower percentages of $\mathrm{CD} 6^{+}$Perforin $^{+}$cells as compared to controls (Figure 4D).

\section{Inhibition of Src Kinases Skews CD56+ Cell Repertoire Undergoing in vitro Cell Differentiation}

It has been reported that Dasatinib, but not Imatinib and Nilotinib, exerts an inhibitory effect on the family of Src kinases: thus, it is possible that the lower numbers of $\mathrm{CD}^{+} 6^{+}$cells, detected in the presence of this compound, may reflect an inhibitory effect on Src kinases occurring at the level of cell precursors $(36,39)$. To test this possibility, $\mathrm{CD} 34^{+} \mathrm{HSC}$ were cultured in appropriate cytokine mix medium in the absence or in the presence of different concentrations of KX2-391 (5, 50,100 , and $200 \mathrm{nM}$ ) a non-selective Src kinase inhibitor, or in the presence of Dasatinib $(200 \mathrm{nM})$. After 15 days of culture, cells were counted. KX2-391 did not significantly impair cell proliferation at different drug concentrations with the exception of highest dose $(200 \mathrm{nM})$, in which an extensive cell death could be detected (Figures 5A,B). Moreover, there were no significant variations in $\mathrm{CD}_{5}{ }^{+}$cell percentages in the presence of lower concentrations of KX2-391 inhibitor as compared to controls (Figure 5C). However, analysis of the cell surface phenotype revealed that KX2-391 could induce substantial modifications of 
A

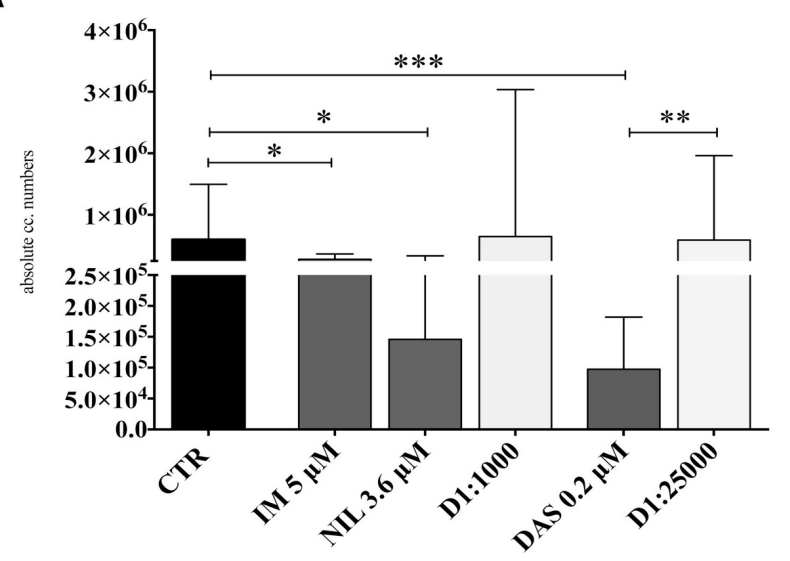

B

CTR

IM

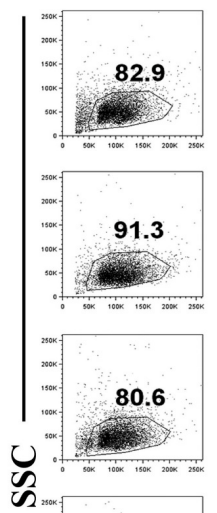

NIL

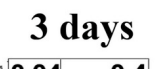

8 days

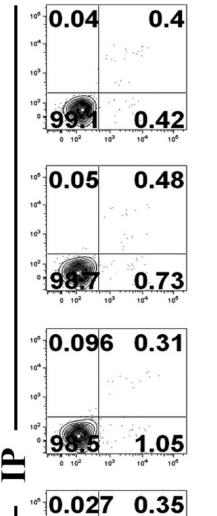

$0.14 \quad 2.29$

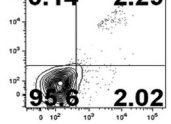

$0.038 \quad 2.02$

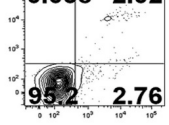

$0.16 \quad 3.28$

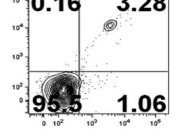

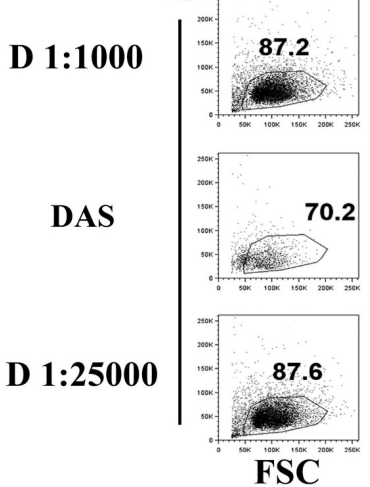

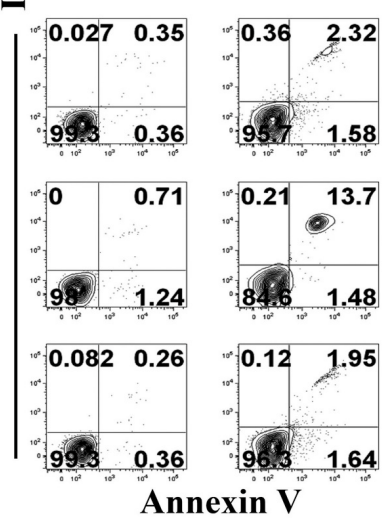

C

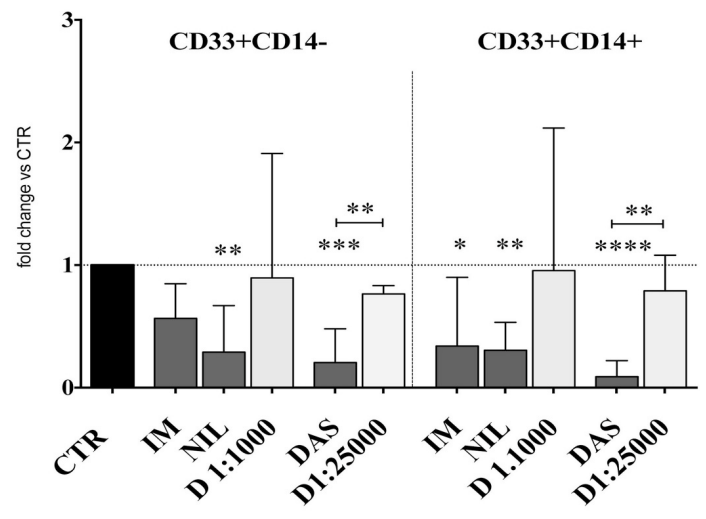

D

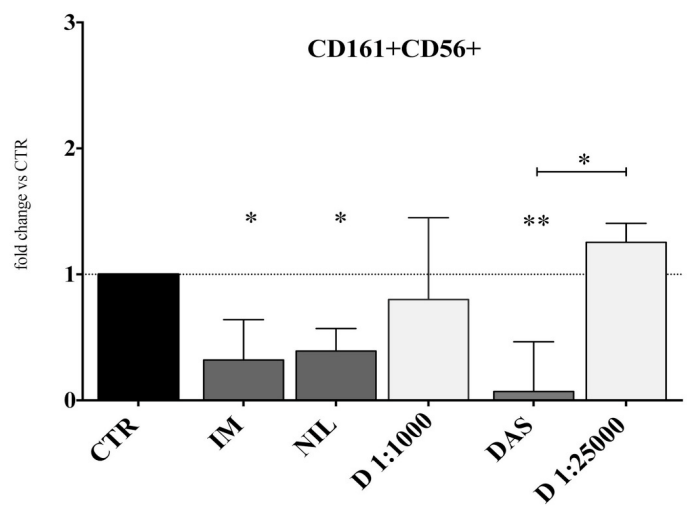

FIGURE 1 | TKI inhibit the in vitro cell differentiation of CD34 ${ }^{+} \mathrm{HSC}$ toward myeloid and lymphoid cells. UCB-CD34 ${ }^{+}$cells were purified and cultured with cytokine-mix medium in the absence (CTR, control) or in the presence of different TKI: Imatinib $5 \mu \mathrm{M}$ (IM) Nilotinib 3,6 $\mu \mathrm{M}$ (NIL), Dasatinib 0,2 $\mu$ M (DAS) at the plasma peak concentrations and DMSO at the corresponding concentrations of the drugs (D 1:1000 and D 1:25000). After 15 days of culture, cells were counted and analyzed by flow-cytometry for the indicated surface markers. (A) The histogram shows the absolute mononucleated cell number recovery in CTR or TKI cultures. The data are represented as the median with interquartile range obtained by ten independent experiments and analyzed by Kruskal-Wallis multiple comparison test $\left({ }^{*} p<\right.$ $0.05 ;{ }^{* *} p<0.005 ;{ }^{* \star *} p<0.0005$ ). (B) Dot plots show the morphological features and Annexin V/PI staining observed in the cell precursors undergoing in vitro NK cell differentiation in the presence of different culturing conditions: control (CTR), Imatinib $5 \mu \mathrm{M}$ (IM), Nilotinib 3,6 $4 \mathrm{M}$ (NIL), Dasatinib 0,2 $\mu \mathrm{M}$ (DAS) and DMSO (D 1:1000 and $D$ 1:25000). The cells were undergone to immunofluorescence tests after 3 and 8 days of culture. (C) The histogram represents the fold change of absolute cell numbers of $\mathrm{CD}_{3} 3^{+} \mathrm{CD} 14^{-}$and $\mathrm{CD} 33^{+} \mathrm{CD} 14^{+}$cells recovered in TKI and DMSO cultures as compared to CTR, arbitrarily normalized to one. The data are expressed as the median values with interquartile range obtained by ten independent experiments. Data obtained in different culturing conditions were compared to CTR and analyzed by Wilcoxon signed-rank test $\left({ }^{*} p<0.05 ;{ }^{* *} p<0.005 ;{ }^{* \star *} p<0.0005 ;{ }^{* \star \star *} p<0.00005\right)$. Comparison between the different TKI culturing conditions and the different DMSO diluition culturing conditions was analyzed by Kruskal-Wallis multiple comparison test $\left({ }^{*} p<0.05 ;{ }^{* *} p<0.005\right)$. (D) The histogram represents the fold change of $\mathrm{CD} 161^{+} \mathrm{CD}_{6} 6^{+}$absolute cell number recovered in the presence of TKI and DMSO as compared to CTR, arbitrarily normalized to one. Data are represented as the median values with interquartile range obtained by ten independent experiments and comparison with CTR was analyzed by Wilcoxon signed-rank test $\left({ }^{*} p<0.05 ; * \star x<0.005\right)$. Comparison between the different TKI culturing conditions and the different DMSO dilution culturing conditions was analyzed by Kruskal-Wallis multiple comparison test $\left({ }^{*} p<0.05\right)$. 


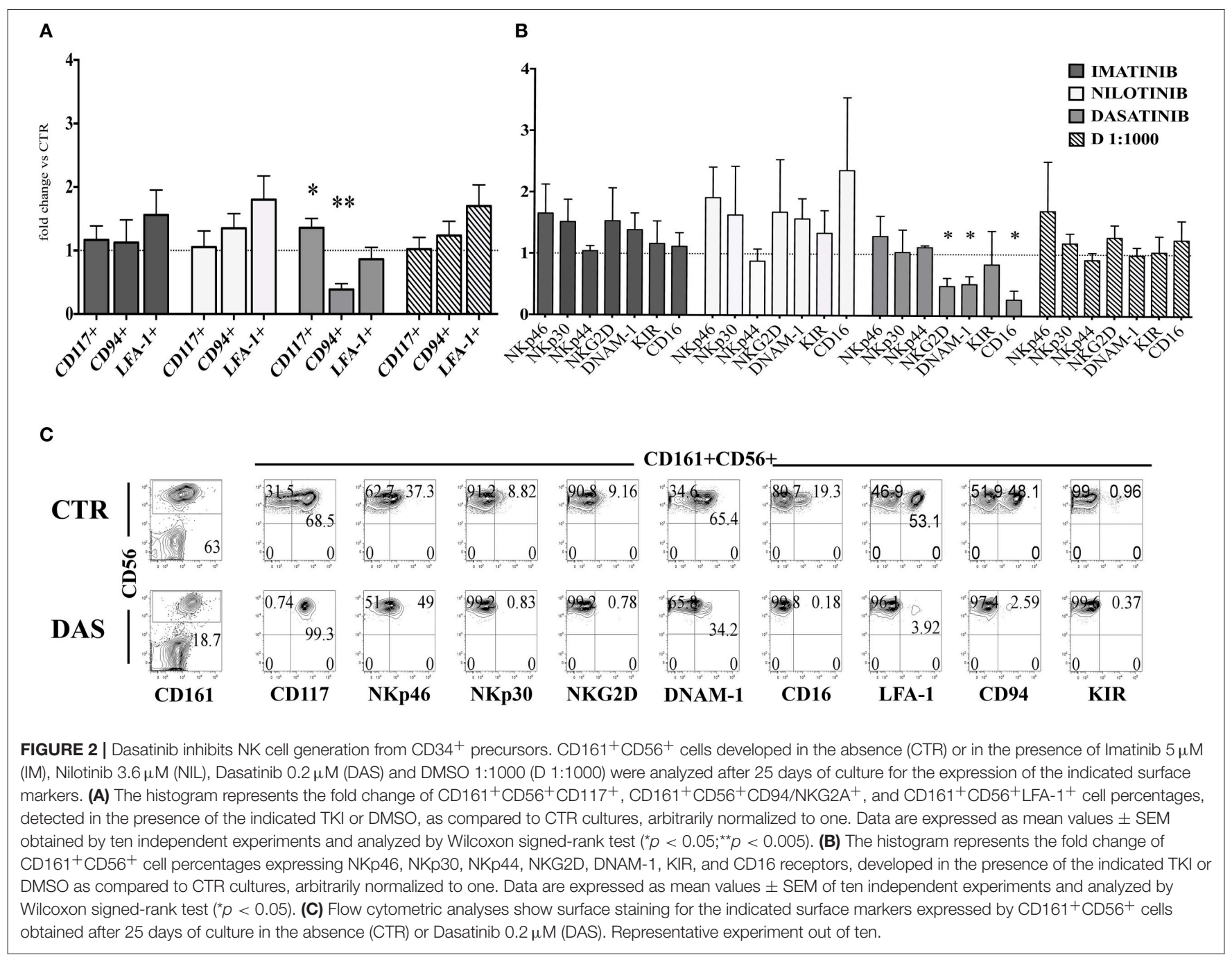

the subset composition within the $\mathrm{CD} 56^{+}$cell population, similar to those detected in the presence of Dasatinib. Thus, as shown in Figures 5D,E, even in the presence of the lowest concentration of KX2-391 (i.e., $5 \mathrm{nM}$ ), there was an increased expression of ROR $\gamma \mathrm{t}$ TF and of CD117, paralleled by the reduced expression of Eomes TF and of CD94/NKG2A. Accordingly, CD56 ${ }^{+}$cells undergoing differentiation in the presence of Dasatinib $200 \mathrm{nM}$ or KX2-391 $5 \mathrm{nM}$, displayed a lower cytolytic activity against K562 target cells as compared to control (Figure 5F).

It has been shown that Dasatinib can inhibit the Signal Transducer and Activator of Transcription (STAT) 3 and STAT 5 protein phosphorylation through the inhibition of Src kinases. Thus, the Dasatinib-mediated effects could also be due to the inhibition of STAT3/STAT5 signaling pathways. To address this issue we investigated whether Dasatinib could inhibit STAT3/STAT5 phosphorylation in CD $34^{+}$cell precursors since early days of in vitro culture. Thus, $\mathrm{CD} 34^{+}$cells were cultured with cytokine mix medium in the absence or in the presence of Dasatinib, and STATs protein phosphorylation was analyzed at different time intervals, i.e., 18/24/48 h of culture. A reduction of pSTAT5 $^{+}$cell percentages was detected while the percentages of pSTAT3 $^{+}$cells were similar or higher than those detected in control cultures at all the time intervals analyzed (Figure 6A). Of note, after $72 \mathrm{~h}$ of culture in the presence of Dasatinib, we could still observe lower $\mathrm{pSTAT}^{+}$cell percentages as compared to control, and increase of CD $117^{+}$cell percentages (Figure 6B). On the other hand, analysis performed at 20 days of culture, showed that $\mathrm{CD}^{+} 6^{+}$cell subsets developed in the presence of Dasatinib, contained higher percentages of pSTAT5 $^{+}$cells as compared to controls, while myeloid cells displayed a marked reduction of both $\mathrm{pSTAT}^{+}$and $\mathrm{pSTAT}^{+}$cells (Figure $6 \mathrm{C}$ ).

\section{DISCUSSION}

In this study we analyzed the effect of the TKI inhibitors Imatinib, Nilotinib, and Dasatinib on NK cell differentiation from UCB-derived $\mathrm{CD} 34^{+}$cell precursors. We show a sharp inhibition of cell proliferation and a reduced recovery of both myeloid and $\mathrm{CD} 161^{+} \mathrm{CD} 56^{+}$lymphoid cells. More importantly, Dasatinib skewed the subset composition of $\mathrm{CD} 161^{+} \mathrm{CD} 56^{+}$ 


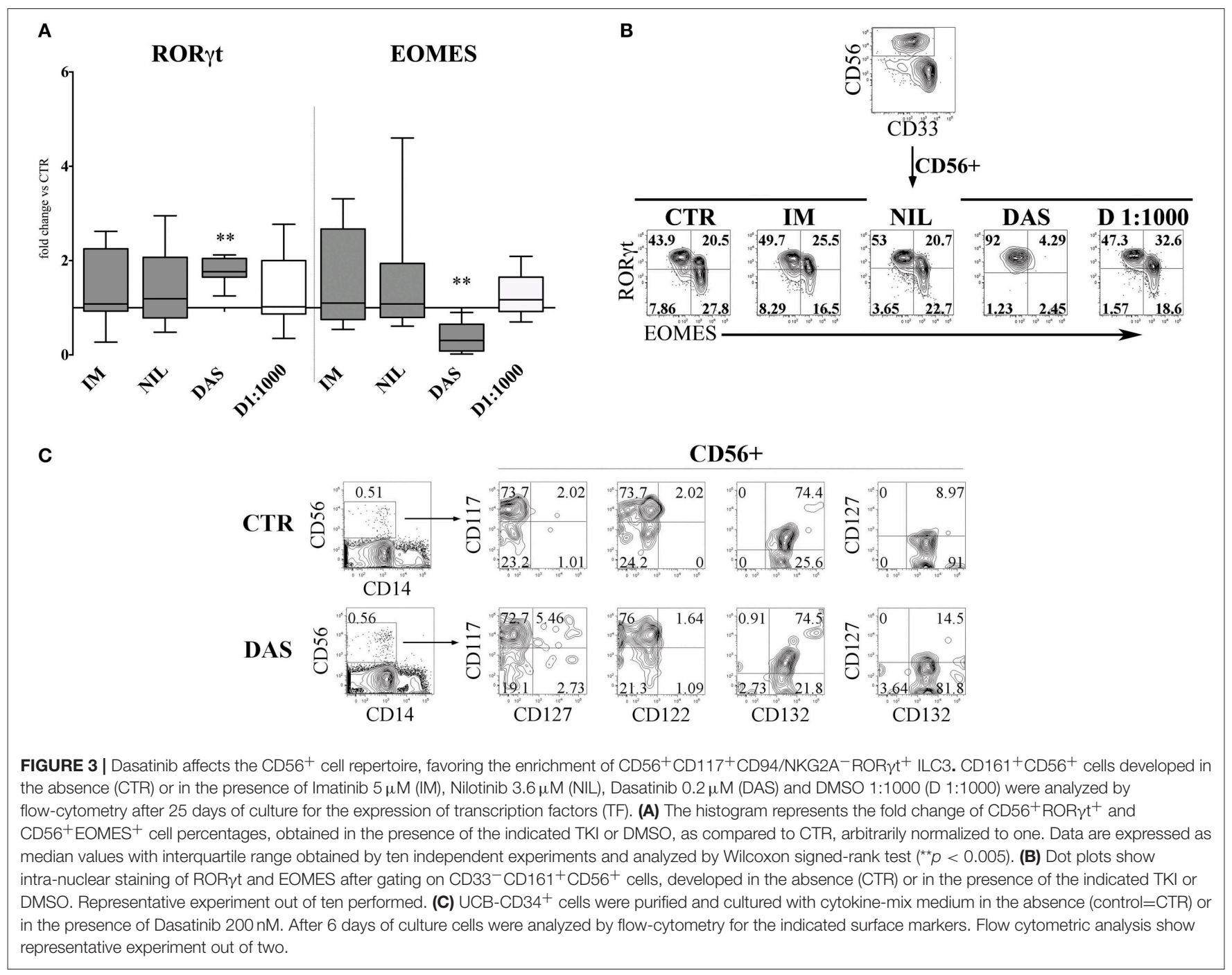

cell population favoring the generation of ROR $\gamma \mathrm{t}^{+} \mathrm{IL}-22^{+}$ILC3 and inhibiting both proliferation and function of cytotoxic NK cells. Experiments using the KX2-391 Src-family kinase inhibitor suggest that the impairment of NK cell generation and function may be consequent to the inhibitory effect mediated by Dasatinib on Src-family kinases and the early impairment of STAT5 signaling in $\mathrm{CD} 34^{+}$cell precursors.

The TKI therapy in CML or $\mathrm{Ph}^{+}$ALL patients has dramatically improved the prognosis of these patients. However, the development of resistance and leukemia relapse, in particular upon therapy discontinuation, still represents a major problem. Thus, in recent years, a major research focus has been to improve both DMR and TFR (8). Notably, a positive clinical outcome in these patients appears to correlate with an efficient immune response allowing the control of the CML residual disease (13). Since NK cells are thought to play a relevant role in this process, it was important to clarify whether TKI could influence not only the repertoire and function of circulating mature NK cells, but also their development from $\mathrm{CD} 34^{+}$ HSC. To this end, we took advantage of an in vitro model of $\mathrm{NK}$ cell differentiation from $\mathrm{CD} 34^{+}$cell precursors that allows the generation of different ILC subsets. In addition, it provides a useful tool to analyze factors/drugs that may modify such process $(27,40)$. In the present experiments, CD $34^{+}$ cells were cultured in the presence of Imatinib, Nilotinib, and Dasatinib at plasmatic peak concentrations, to reproduce drug concentrations present in $\mathrm{PB}$ and $\mathrm{BM}$ of TKI-treated patients. An inhibitory effect of TKI on precursor cell proliferation could be expected, since these compounds are known to interfere with the SCF/c-KIT (CD117) transduction pathway that plays a key role in the early steps of $\mathrm{CD} 34^{+}$cell activation and proliferation $(37,41)$. However, the impairment of cell proliferation and recovery was associated with an increase of programmed cell death only in Dasatinib culture condition, in which apoptosis was clearly detectable during the first week of culture. Although all TKI analyzed induced a decrease of $\mathrm{CD} 161^{+} \mathrm{CD}_{56}{ }^{+}$cell recovery, Dasatinib exerted a more marked inhibitory effect. Moreover, only Dasatinib significantly skewed the $\mathrm{CD} 161^{+} \mathrm{CD}_{56}{ }^{+}$cell repertoire favoring $\mathrm{CD} 117^{+} \mathrm{CD} 94^{-} \mathrm{LFA}-$ $1^{-}-\mathrm{ROR} \mathrm{t}^{+}$ILC3, while CD $117^{-} \mathrm{CD}^{+} 4^{+} \mathrm{LFA}^{-}{ }^{+}$Eomes $^{+} \mathrm{NK}$ 


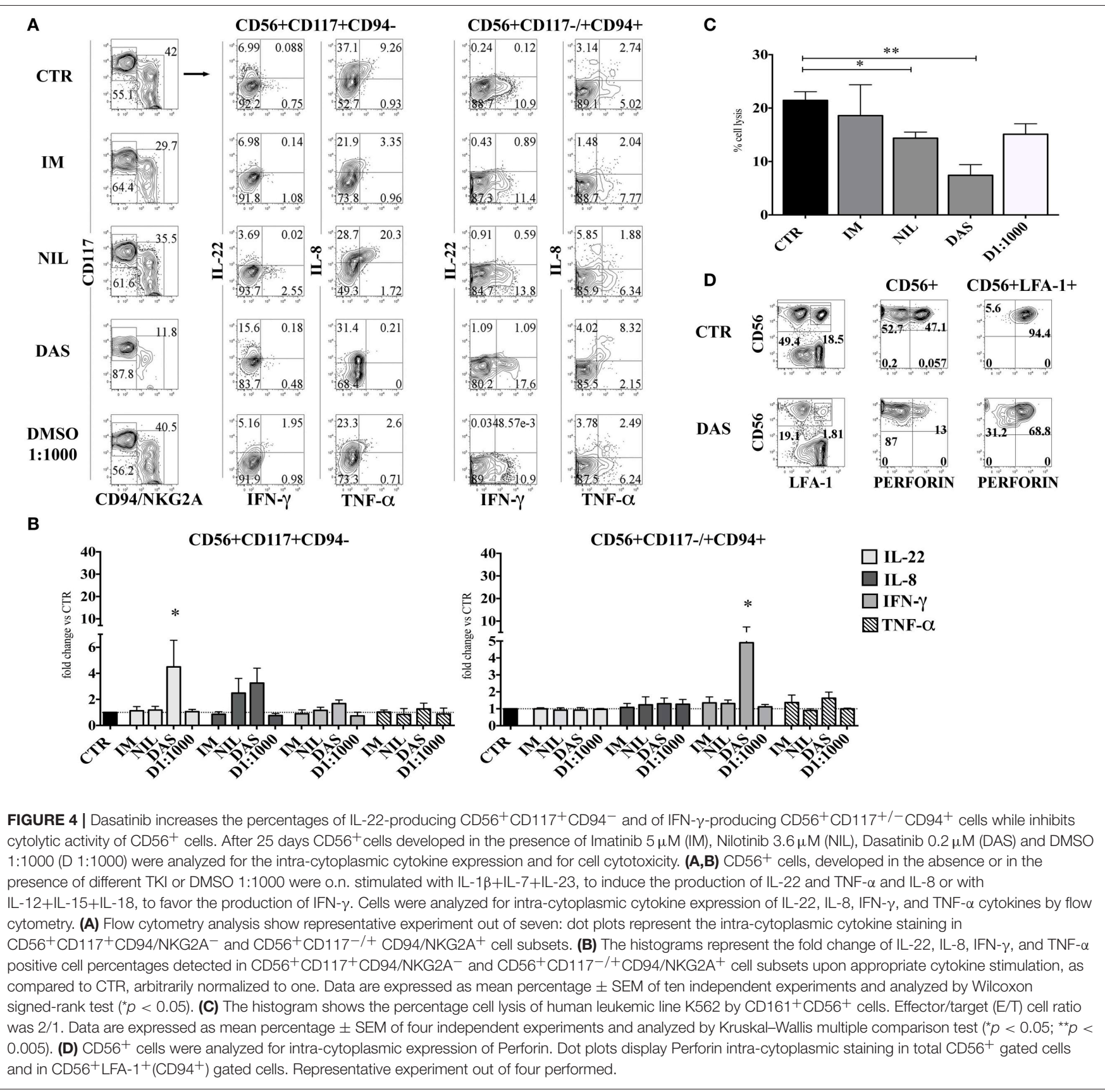

cells were sharply reduced. The effect of Dasatinib on ILC commitment was detectable at early stages, since analysis performed at day 6 of culture revealed an increase of $\mathrm{CD} 117^{+} \mathrm{CD} 127^{+} \mathrm{CD} 132^{+}$cells, representing ILC precursors, while CD122 expression was undetectable. Previous studies on factors that may influence human ILC in vitro development, have shown that the presence of SCF is required to favor the in vitro differentiation of ILC3 in the presence of IL-7 or IL15 , while IL-15 and IL-7, alone or in combination with other pro-inflammatory cytokines, skew precursor cell differentiation toward NK cells $(40,42)$.
The SCF/c-kit transduction pathway involves STAT3 protein phosphorylation, IL-15 pathway preferentially uses STAT5 signaling protein, while IL-7 can exploit both $(37,43)$. It has been shown that Dasatinib inhibits the STAT3 and STAT5 signaling pathways through the inhibition of Src kinases, leading to a durable inhibition of STAT5 phosphorylation, but only a transient inhibition of STAT3 phosphorylation in $\mathrm{CD} 34^{+}$cells isolated from CML patients at diagnosis (39). Our analysis of STAT3/STAT5 phosphorylation in $\mathrm{CD} 34^{+} \mathrm{HSC}$ revealed a higher and durable reduction of pSTAT5 ${ }^{+}$cells as compared to $\mathrm{pSTAT3}^{+}$cells upon cell culture with Dasatinib during first 


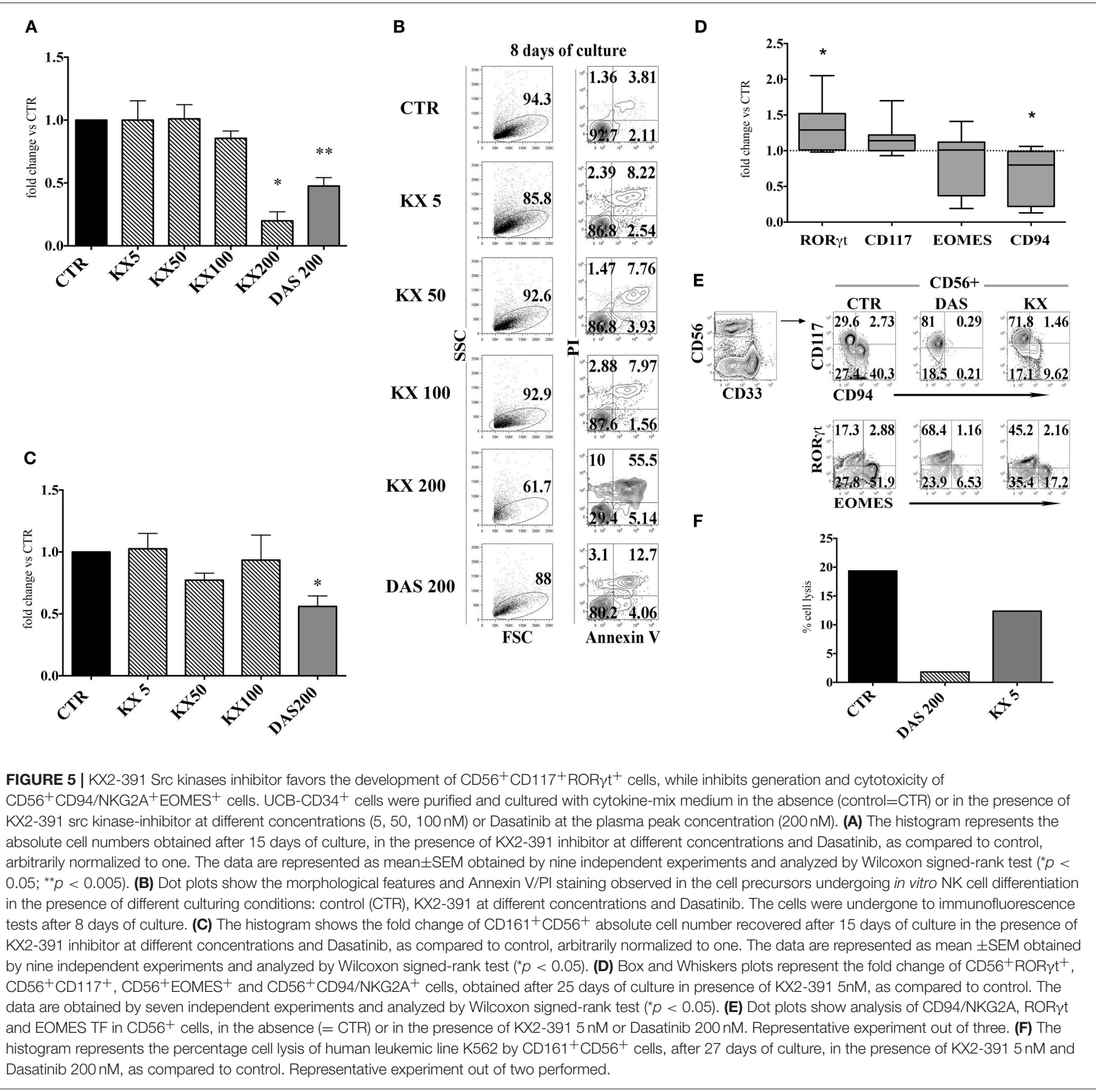

days of culture. Thus, it is conceivable that the early expression of CD117 and CD127 on Dasatinib-treated cells may favor the SCF/CD117- and IL-7/CD127-mediated STAT3 transduction triggering pathway, thus favoring ILC precursors proliferation and survival.

Functional analyses indicate that Dasatinib does not affect cytokine production by ILC3 but rather induces increases of the percentages of $\mathrm{CD} 56^{+} \mathrm{CD} 117^{+} \mathrm{ROR}_{\gamma \mathrm{t}^{+}} \mathrm{IL}-22$ producing cells. Interestingly, the few $\mathrm{NK}$ cells, undergoing differentiation in the presence of Dasatinib, contained higher percentages of IFN$\gamma^{+}$cells. We also detected a slight increase of IL- $8^{+} /$IFN- $\gamma^{+}$ILC3 undergoing differentiation in the presence of Dasatinib. It has been reported that lymphocyte mobilization in Dasatinib-treated patients is frequently associated with adverse effects such as pleural effusion, autoimmune-like syndromes and colitis (29). Of note, ILC3 are thought to play a relevant role in intestinal inflammation (25). In addition, they may exacerbate intestinal inflammation due to their ability to differentiate toward IFN$\gamma$-producing ILC1 cells upon IL-12 stimulation (44). Thus, the inflammatory side effects induced by Dasatinib in mucosal tissues may reflect, at least in part, increases in the production of IL-22, IL- 8 , and IFN- $\gamma$ by ILC. Of note, the increase of IFN- $\gamma$-expressing 
A

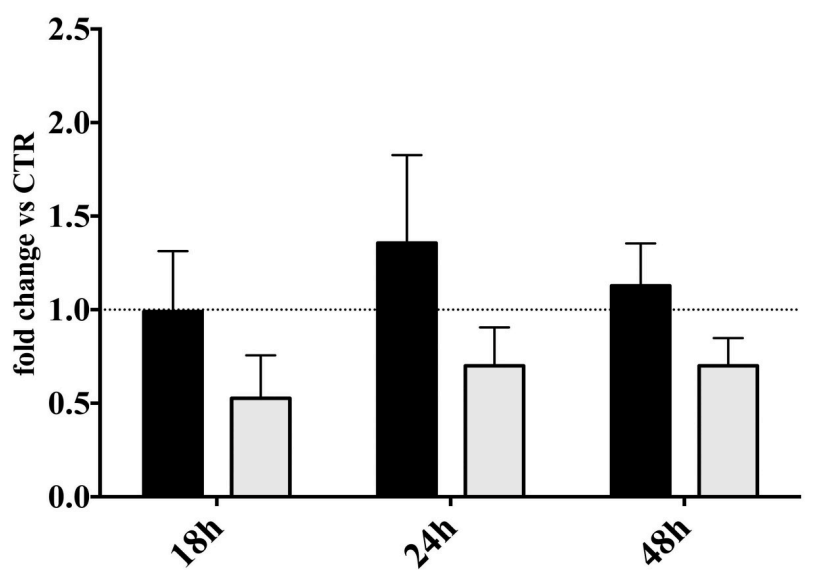

pSTAT3

$\square$ pSTAT5
B

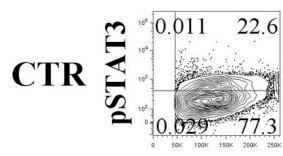

DAS
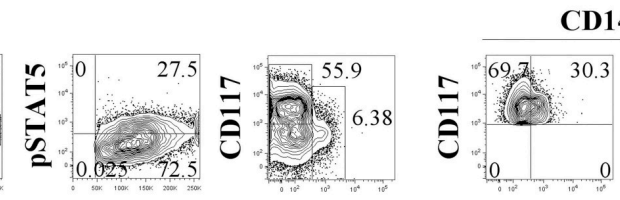

CD14-CD117+
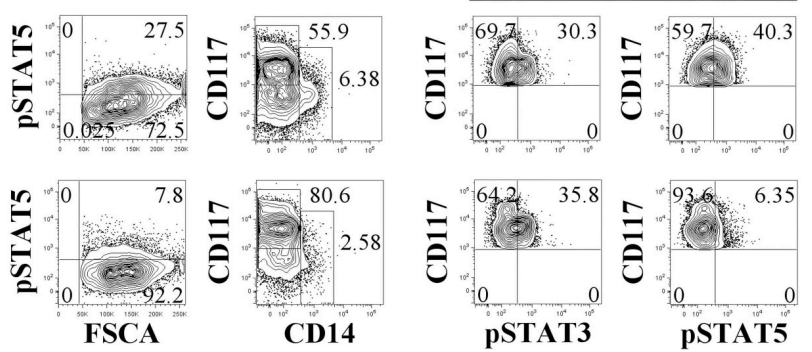

C

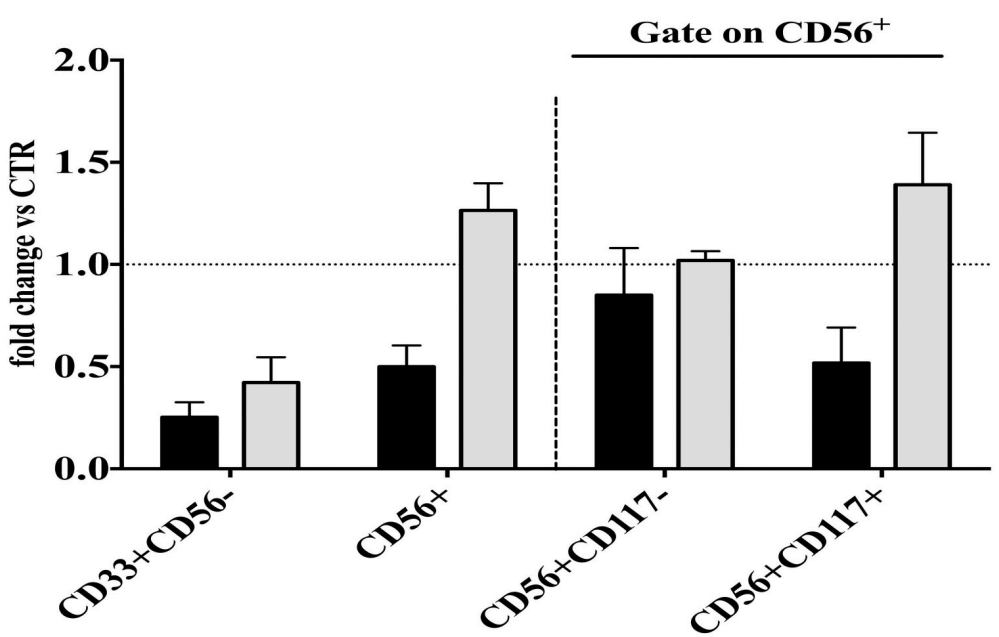

FIGURE 6 | Analysis of the Dasatinib-mediated effect on STAT3 and STAT5 phosphorylation in CD34 ${ }^{+}$cells undergoing differentiation toward CD56 ${ }^{+}$cells at different culture time intervals. (A) UCB-CD34+ ${ }^{+}$cells were isolated and cultured with cytokine-mix medium, in the absence or in the presence of Dasatinib $200 \mathrm{nM}$ for 18,24 , and $48 \mathrm{~h}$. Cells were analyzed for the expression of PSTAT3 and pSTAT5 signaling proteins. The histograms show the fold changes of CD34+ ${ }^{+}$STAT3 ${ }^{+}$and

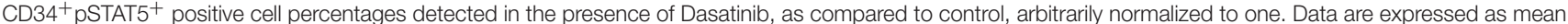
values \pm SEM obtained by four independent experiments. (B) UCB-CD34+ cells were isolated and cultured with cytokine-mix medium, in the absence or in the presence of Dasatinib $200 \mathrm{nM}$ for $72 \mathrm{~h}$. Flow cytometry analyses show the intra-cytoplasmic expression of pSTAT3 and pSTAT5 on total cell population and on CD $14^{-}$CD $117^{+}$gated cells. (C) $\mathrm{CD}^{+} 6^{+}$cells obtained from UCB-CD34+ ${ }^{+}$cells after 20 days of culture, in the absence (CTR) or in the presence of Dasatinib $200 \mathrm{nM}$ were analyzed for the expression of pSTAT3 and pSTAT5 signaling proteins. The histogram shows the fold change of $\mathrm{CD}^{2} 6^{+} \mathrm{pSTAT3}^{+}$and $\mathrm{CD} 6^{+} \mathrm{pSTAT5} 5^{+}$cell percentages detected in the presence of Dasatinib, as compared to control, arbitrarily normalized to one. Data are expressed as mean values \pm SEM obtained by four independent experiments. 


\section{No Treatment (CTR)}

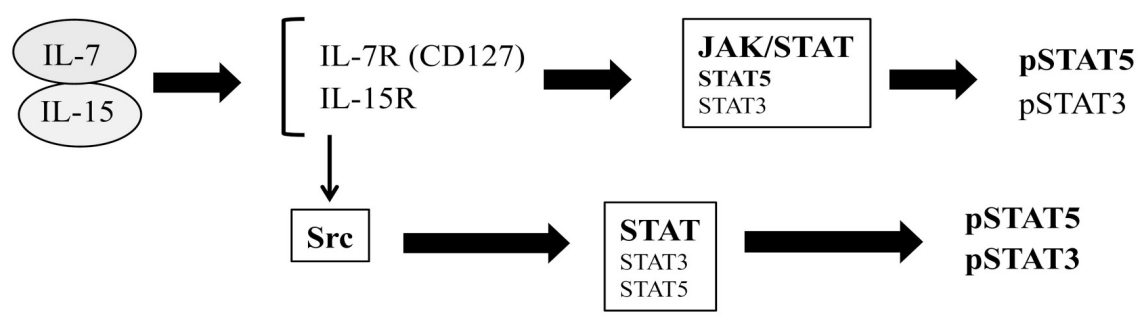

\section{Dasatinib}

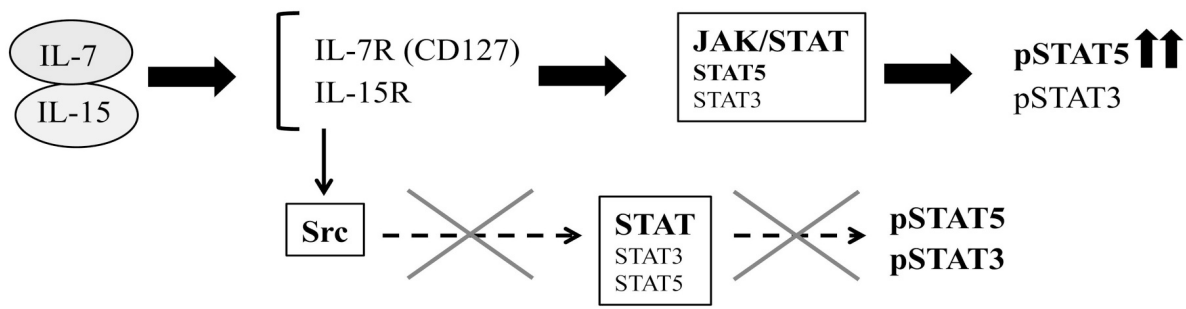

FIGURE 7 | Schematic representation of potential effects of Dasatinib on IL-7/IL-15 transduction pathways. IL-7 and IL-15 cytokines can signal both through the JAK-STAT and the Src pathways.After 20 days of culture, in the control condition, the cytokine receptors engagement by IL-7 and IL-15 leads both to JAK- and SrcSTAT-mediated recruitment and phosphorylation. In the presence of Dasatinib, Src-mediated STAT phosphorylation pathway is abrogated, while cytokine-driven JAK-activation pathway would provide compensatory signals, allowing STAT5 phosphorylation.

$\mathrm{CD}^{+} 6^{+}$cells detectable after 25 days of culture in the presence of Dasatinib, paralleled the increase of $\mathrm{CD}^{2} 6^{+} \mathrm{pSTAT}^{+}$cell percentages. These data may suggest that a prolonged exposure to IL-7 and IL-15 may provide compensatory signals, allowing lymphoid cell cytokine production even in the presence of a chronic exposure to Dasatinib (45) (Figure 7).

The cytolytic activity of $\mathrm{CD}^{+} 6^{+} \mathrm{NK}$ cells developed in the presence of Dasatinib was impaired. It is conceivable that the reduction of cytotoxicity may reflect the lower number of mature NK cells however, we could also detect a decrease of Perforin content in the few mature NK cells present in Dasatinib cultures. In addition, it should be considered the inhibitory effect exerted by Dasatinib on Src kinases and on ERK protein phosphorylation (p-ERK), required for the cytolytic degranulation process (39, $46,47)$. Indeed, our experiments using KX2-391 inhibitor would confirm that the effect on the $\mathrm{CD}^{2} 6^{+}$cell repertoire induced by Dasatinib, may be due to the impairment of Src kinase pathway. Notably, KX2-391 induced massive cell apoptosis at the concentration of $200 \mathrm{nM}$ while at lower concentrations the proportions of Annexin $\mathrm{V}^{+}$cells were low. However, the use of KX2-391 at lower concentrations skewed the $\mathrm{CD}^{+} 6^{+}$ cell repertoire toward $\mathrm{CD} 56^{+} \mathrm{CD} 117^{+} \mathrm{CD} 94 / \mathrm{NKG} 2 \mathrm{~A}^{-} \mathrm{ROR} \gamma \mathrm{t}^{+}$ ILC3, similar to what detected in cultures performed in the presence of Dasatinib.

Studies in mice models have suggested that IL-15/STAT5 pathway may represent a central node in NK cell homeostasis and in the TF network that instructs ILC development (4851). Our data indicate that exposure to Src kinase inhibitors may play a relevant a role in the inhibition of human $\mathrm{NK}$ cell development and in the acquisition of cytolytic activity, while the cytokine-driven STAT3 and STAT5 activation pathway may overcome Dasatinib-mediated inhibition and favor the preferential survival of $\mathrm{CD} 117^{+} \mathrm{CD} 127^{+}$ILC3 precursors and the subsequent cytokine production by both mature ILC3 and NK cells detectable at later time culture intervals.

It has been reported that Dasatinib, may induce cytotoxic $\mathrm{CD}_{56}{ }^{+} \mathrm{CD}_{57}{ }^{+} \mathrm{NK}$ cell mobilization in the PB and BM of TKItreated patients $(29-31,52)$. It is conceivable that different effects detectable in vitro vs. in vivo of Dasatinib-treatment may be consequent to the short half-life of the drug in plasma vs. its stable levels in cell cultures (53). Notably, it has been suggested that the incidence of lymphocytosis does not correlate with DMR, while the numbers and percentages of circulating cytotoxic NK cells and CTL were significantly higher in patients with DMR as compared to those with no DMR (30). The high degree of heterogeneity of cases analyzed may contribute to the variability of responses: patients may undergo different TKI administration protocols, and the immune system status (immunosuppression, viral reactivation, therapy-related BM/ lymphoid organs exhaustion) may greatly influence immune cell repertoire and function, having an impact on the clinical outcome of CML-treated patients (13). 
In conclusion, our results suggest that Dasatinib may affect NK cell development, and offer new clues to better understand the signaling pathways that regulate development and proliferation of precursors toward NK cells and other ILC. The Dasatinib-induced skewing of ILC differentiation toward ILC3 and increasing of IFN- $\gamma$ producing cells should be considered in patients with severe therapy-induced side effects or with limited responses to therapy. Moreover, in Dasatinibtreated patients, it will be important to better characterize both the lymphoid cell precursors and the mature cytolytic effector cells present in patients BM, i.e., the site where drug-resistant leukemic clones primarily reside (54). Finally, our study, could offer a clue for identifying new tools to design individualized timing and dosing of Dasatinib administration in order to obtain optimal responses without compromising the NK cell-based immunotherapeutic intervention.

\section{ETHICS STATEMENT}

The ethics committe that approved the study was Comitato Etico Regionale Liguria- Ospedale San Martino. Samples were from Liguria Cord Blood Bank. This study was carried out in accordance with the recommendations of UE guidelines for Good Clinical Practice and Comitato Etico Regionale LiguriaOspedale San Martino with written informed consent from all subjects. All subjects gave written informed consent in accordance with the Declaration of Helsinki. The protocol was

\section{REFERENCES}

1. Kantarjian H, Shah NP, Hochhaus A, Cortes J, Shah S, Ayala M, et al. Dasatinib versus imatinib in newly diagnosed chronic-phase chronic myeloid leukemia. N Engl J Med. (2010) 362:2260-70. doi: 10.1056/NEJMoa10 02315

2. Saglio G, Kim DW, Issaragrisil S, le Coutre P, Etienne G, Lobo C, et al. Nilotinib versus imatinib for newly diagnosed chronic myeloid leukemia. $N$ Engl J Med. (2010) 362:2251-9. doi: 10.1056/NEJMoa0912614

3. Leoni V, Biondi A. Tyrosine kinase inhibitors in BCR-ABL positive acute lymphoblastic leukemia. Haematologica (2015) 100:295-9. doi: 10.3324/haematol.2015.124016

4. Graham SM, Jorgensen HG, Allan E, Pearson C, Alcorn MJ, Richmond L, et al. Primitive, quiescent, Philadelphia-positive stem cells from patients with chronic myeloid leukemia are insensitive to STI571 in vitro. Blood (2002) 99:319-25. doi: 10.1182/blood.V99.1.319

5. Chu S, McDonald T, Lin A, Chakraborty S, Huang Q, Snyder DS, et al. Persistence of leukemia stem cells in chronic myelogenous leukemia patients in prolonged remission with imatinib treatment. Blood (2011) 118:5565-72. doi: 10.1182/blood-2010-12-327437

6. Jabbour E, Cortes J, Ravandi F, O’Brien S, Kantarjian H. Targeted therapies in hematology and their impact on patient care: chronic and acute myeloid leukemia. Semin Hematol. (2013) 50:271-83. doi: 10.1053/j.seminhematol.2013.09.006

7. Miranda MB, Johnson DE. Signal transduction pathways that contribute to myeloid differentiation. Leukemia (2007) 21:1363-77. doi: 10.1038/sj.leu.2404690

8. Hehlmann R. Innovation in hematology. Perspectives: CML 2016. Haematologica (2016). 101:657-9. doi: 10.3324/haematol.2016.142877

9. Imagawa J, Tanaka H, Okada $M$, Nakamae $H$, Hino $M$, Murai $K$, et al. Discontinuation of dasatinib in patients with chronic myeloid leukaemia who have maintained deep molecular response for longer than 1 year approved by the Comitato Etico Regionale Liguria- Ospedale San Martino.

\section{AUTHOR CONTRIBUTIONS}

LD designed the experimental plan and performed experiments. EM designed the first set of experiments. LM analyzed results. $\mathrm{CV}$ designed the experimental plan, analyzed results and wrote the paper. MCM analyzed results. All the authors contributed to the critical review of the manuscript. CV and MM share senior authorship.

\section{FUNDING}

This work was supported by grants awarded by: Associazione Italiana per la Ricerca sul Cancro (AIRC): IG 2014 project Id. 15283 (LM), IG 2017 Id. 19920 (LM) and Special Program Molecular Clinical Oncology 5x1000 project Id. 9962 (LM); IRCCS Policlinico San Martino 5x1000 2011 and 5x1000 2013 (MCM). Fondi Ricerca Ateneo 2016 (FRA) Università degli Studi di Genova (CV).

\section{ACKNOWLEDGMENTS}

The authors would like to thank: Dott. A. Bo and all collaborators of Liguria Cord Blood Bank; Giulia Cucci for secretarial assistance.
(DADI trial): a multicentre phase 2 trial. Lancet Haematol. (2015) 2:e528-35. doi: 10.1016/S2352-3026(15)00196-9

10. Etienne G, Guilhot J, Rea D, Rigal-Huguet F, Nicolini F, Charbonnier A, et al. Long-term follow-up of the french stop imatinib (STIM1) study in patients with chronic myeloid leukemia. J Clin Oncol. (2017) 35:298-305. doi: 10.1200/JCO.2016.68.2914

11. Castagnetti F, Gugliotta G, Breccia M, Stagno F, Iurlo A, Albano F, et al. Long-term outcome of chronic myeloid leukemia patients treated frontline with imatinib. Leukemia (2015) 29:1823-31. doi: 10.1038/leu. 2015.152

12. Hughes A, Clarson J, Tang C, Vidovic L, White DL, Hughes TP, et al. CML patients with deep molecular responses to TKI have restored immune effectors and decreased PD-1 and immune suppressors. Blood (2017) 129:1166-76. doi: 10.1182/blood-2016-10-745992

13. Hughes A, Yong ASM. Immune effector recovery in chronic myeloid leukemia and treatment-free remission. Front Immunol. (2017) 8:469. doi: 10.3389/fimmu.2017.00469

14. Pende D, Marcenaro S, Falco M, Martini S, Bernardo ME, Montagna $\mathrm{D}$, et al. Anti-leukemia activity of alloreactive NK cells in KIR ligandmismatched haploidentical HSCT for pediatric patients: evaluation of the functional role of activating KIR and redefinition of inhibitory KIR specificity. Blood (2009) 113:3119-29. doi: 10.1182/blood-2008-06164103

15. Vivier E, Raulet DH, Moretta A, Caligiuri MA, Zitvogel L, Lanier LL, et al. Innate or adaptive immunity? The example of natural killer cells. Science (2011) 331:44-9. doi: 10.1126/science.1198687

16. Moretta L, Pietra G, Montaldo E, Vacca P, Pende D, Falco M, et al. Human NK cells: from surface receptors to the therapy of leukemias and solid tumors. Front Immunol. (2014) 5:87. doi: 10.3389/fimmu.2014. 00087

17. Locatelli F, Merli P, Pagliara D, Li Pira G, Falco M, Pende D, et al. Outcome of children with acute leukemia given HLA-haploidentical HSCT 
after alphabeta T-cell and B-cell depletion. Blood (2017) 130:677-85. doi: 10.1182/blood-2017-04-779769

18. Locatelli F, Pende D, Falco M, Della Chiesa M, Moretta A, Moretta L. nk cells mediate a crucial graft-versus-leukemia effect in haploidenticalHSCT to cure high-risk acute leukemia. Trends Immunol. (2018) 39:577-90. doi: 10.1016/j.it.2018.04.009

19. Pende D, Spaggiari GM, Marcenaro S, Martini S, Rivera P, Capobianco A, et al. Analysis of the receptor-ligand interactions in the natural killer-mediated lysis of freshly isolated myeloid or lymphoblastic leukemias: evidence for the involvement of the Poliovirus receptor (CD155) and Nectin-2 (CD112). Blood (2005) 105:2066-73. doi: 10.1182/blood-2004-09-3548

20. Cooley S, Trachtenberg E, Bergemann TL, Saeteurn K, Klein J, Le CT, et al. Donors with group B KIR haplotypes improve relapse-free survival after unrelated hematopoietic cell transplantation for acute myelogenous leukemia. Blood (2009) 113:726-32. doi: 10.1182/blood-2008-07171926

21. Venstrom JM, Pittari G, Gooley TA, Chewning JH, Spellman S, Haagenson M, et al. HLA-C-dependent prevention of leukemia relapse by donor activating KIR2DS1. N Engl J Med. (2012) 367:805-16. doi: 10.1056/NEJMoa12 00503

22. Montaldo E, Del Zotto G, Della Chiesa M, Mingari MC, Moretta A, De Maria A, et al. Human NK cell receptors/markers: a tool to analyze NK cell development, subsets and function. Cytometry A (2013) 83:702-13. doi: $10.1002 /$ cyto.a.22302

23. Yu J, Freud AG, Caligiuri MA. Location and cellular stages of natural killer cell development. Trends Immunol. (2013) 34:573-82. doi: $10.1016 /$ j.it.2013.07.005

24. Montaldo E, Vacca P, Moretta L, Mingari MC. Development of human natural killer cells and other innate lymphoid cells. Semin Immunol. (2014) 26:107-13. doi: 10.1016/j.smim.2014.01.006

25. Klose CS, Artis D. Innate lymphoid cells as regulators of immunity, inflammation and tissue homeostasis. Nat Immunol. (2016) 17:765-74. doi: 10.1038/ni.3489

26. Tang Q, Ahn YO, Southern P, Blazar BR, Miller JS, Verneris MR. Development of IL-22-producing NK lineage cells from umbilical cord blood hematopoietic stem cells in the absence of secondary lymphoid tissue. Blood (2011) 117:4052-5. doi: 10.1182/blood-2010-09-303081

27. Montaldo E, Vitale C, Cottalasso F, Conte R, Glatzer T, Ambrosini P, et al. Human NK cells at early stages of differentiation produce CXCL8 and express CD161 molecule that functions as an activating receptor. Blood (2012) 119:3987-96. doi: 10.1182/blood-2011-09-379693

28. Krieg S, Ullrich E. Novel immune modulators used in hematology: impact on NK cells. Front Immunol. (2012) 3:388. doi: 10.3389/fimmu.2012. 00388

29. Mustjoki S, Ekblom M, Arstila TP, Dybedal I, Epling-Burnette PK, Guilhot F, et al. Clonal expansion of T/NK-cells during tyrosine kinase inhibitor dasatinib therapy. Leukemia (2009) 23:1398-405. doi: 10.1038/leu. 2009.46

30. Iriyama N, Fujisawa S, Yoshida C, Wakita H, Chiba S, Okamoto S, et al. Early cytotoxic lymphocyte expansion contributes to a deep molecular response to dasatinib in patients with newly diagnosed chronic myeloid leukemia in the chronic phase: results of the D-first study. Am J Hematol. (2015) 90:819-24. doi: 10.1002/ajh.24096

31. El Missiry M, Adnan Awad S, Rajala HL, Al-Samadi A, Ekblom M, Markevan B, et al. Assessment of bone marrow lymphocytic status during tyrosine kinase inhibitor therapy and its relation to therapy response in chronic myeloid leukaemia. J Cancer Res Clin Oncol. (2016) 142:1041-50. doi: 10.1007/s00432-015-2101-4

32. Ilander M, Olsson-Stromberg U, Schlums H, Guilhot J, Bruck O, Lahteenmaki $\mathrm{H}$, et al. Increased proportion of mature NK cells is associated with successful imatinib discontinuation in chronic myeloid leukemia. Leukemia (2017) 31:1108-16. doi: 10.1038/leu.2016.360

33. Kreutzman A, Jaatinen T, Greco D, Vakkila E, Richter J, Ekblom M, et al, Killer-cell immunoglobulin-like receptor gene profile predicts good molecular response to dasatinib therapy in chronic myeloid leukemia. Exp Hematol. (2012) 40:906-13 el. doi: 10.1016/j.exphem.2012.07.007
34. La Nasa G, Caocci G, Littera R, Atzeni S, Vacca A, Mulas O, et al. Homozygosity for killer immunoglobin-like receptor haplotype A predicts complete molecular response to treatment with tyrosine kinase inhibitors in chronic myeloid leukemia patients. Exp Hematol. (2013) 41:424-31. doi: 10.1016/j.exphem.2013.01.008

35. Caocci G, Martino B, Greco M, Abruzzese E, Trawinska MM, Lai S, et al. Killer immunoglobulin-like receptors can predict TKI treatment-free remission in chronic myeloid leukemia patients. Exp Hematol. (2015) 43:1015-8 e1. doi: 10.1016/j.exphem.2015.08.004

36. Rane SG, Reddy EP. JAKs, STATs and Src kinases in hematopoiesis. Oncogene (2002) 21:3334-58. doi: 10.1038/sj.onc.1205398

37. Kent D, Copley M, Benz C, Dykstra B, Bowie M, Eaves C. Regulation of hematopoietic stem cells by the steel factor/KIT signaling pathway. Clin Cancer Res. (2008) 14:1926-30. doi: 10.1158/1078-0432.CCR07-5134

38. Lowell CA. Src-family and Syk kinases in activating and inhibitory pathways in innate immune cells: signaling cross talk. Cold Spring Harb Perspect Biol. (2011) 3:a002352. doi: 10.1101/cshperspect.a002352.

39. Konig H, Copland M, Chu S, Jove R, Holyoake TL, Bhatia R. Effects of dasatinib on SRC kinase activity and downstream intracellular signaling in primitive chronic myelogenous leukemia hematopoietic cells. Cancer Res. (2008) 68:9624-33. doi: 10.1158/0008-5472.CAN-08-1131

40. Ambrosini P, Loiacono F, Conte R, Moretta L, Vitale C, Mingari MC. IL-1beta inhibits ILC3 while favoring NK-cell maturation of umbilical cord blood CD34(+) precursors. Eur J Immunol. (2015) 45:2061-71. doi: 10.1002/eji.201445326.

41. Ohanian M, Cortes J, Kantarjian H, Jabbour E. Tyrosine kinase inhibitors in acute and chronic leukemias. Expert Opin Pharmacother. (2012) 13:927-38. doi: $10.1517 / 14656566.2012 .672974$

42. Montaldo E, Teixeira-Alves LG, Glatzer T, Durek P, Stervbo U, Hamann W, et al. Human RORgammat $(+) \mathrm{CD} 34(+)$ cells are lineage-specified progenitors of group 3 RORgammat(+) innate lymphoid cells. Immunity (2014) 41:9881000. doi: 10.1016/j.immuni.2014.11.010

43. Rochman Y, Spolski R, Leonard WJ. New insights into the regulation of T cells by gamma(c) family cytokines. Nat Rev Immunol. (2009) 9:480-90. doi: $10.1038 /$ nri2580

44. Bernink JH, Peters CP, Munneke M, te Velde AA, Meijer SL, Weijer K, et al. Human type 1 innate lymphoid cells accumulate in inflamed mucosal tissues. Nat Immunol. (2013) 14:221-9. doi: 10.1038/ni.2534

45. Johnson FM, Saigal B, Tran H, Donato NJ. Abrogation of signal transducer and activator of transcription 3 reactivation after Src kinase inhibition results in synergistic antitumor effects. Clin Cancer Res. (2007) 13:4233-44. doi: 10.1158/1078-0432.CCR-06-2981

46. Blake SJ, Bruce Lyons A, Fraser CK, Hayball JD, Hughes TP. Dasatinib suppresses in vitro natural killer cell cytotoxicity. Blood (2008) 111:4415-6. doi: 10.1182/blood-2008-02-138701

47. Salih J, Hilpert J, Placke T, Grunebach F, Steinle A, Salih HR, et al. The BCR/ABL-inhibitors imatinib, nilotinib and dasatinib differentially affect NK cell reactivity. Int J Cancer (2010) 127:2119-28. doi: 10.1002/ijc. 25233

48. Delconte RB, Shi W, Sathe P, Ushiki T, Seillet C, Minnich M, et al. The helix-loop-helix protein ID2 governs NK cell fate by tuning their sensitivity to interleukin-15. Immunity (2016) 44:103-15. doi: 10.1016/j.immuni.2015.12.007

49. Rankin LC, Girard-Madoux MJ, Seillet C, Mielke LA, Kerdiles Y, Fenis A, et al. Complementarity and redundancy of IL-22-producing innate lymphoid cells. Nat Immunol. (2016) 17:179-86. doi: 10.1038/ni.3332

50. Robinette ML, Bando JK, Song W, Ulland TK, Gilfillan S, Colonna M. IL15 sustains IL-7R-independent ILC2 and ILC3 development. Nat Commun. (2017) 8:14601. doi: 10.1038/ncomms14601

51. Villarino AV, Sciume G, Davis FP, Iwata S, Zitti B, Robinson GW, et al. Subset- and tissue-defined STAT5 thresholds control homeostasis and function of innate lymphoid cells. J Exp Med. (2017) 214:2999-3014. doi: 10.1084/jem.20150907

52. Hayashi Y, Nakamae H, Katayama T, Nakane T, Koh H, Nakamae M, et al. Different immunoprofiles in patients with chronic myeloid leukemia treated 
with imatinib, nilotinib or dasatinib. Leuk Lymphoma (2012) 53:1084-9. doi: 10.3109/10428194.2011.647017

53. Iriyama N, Hatta $\mathrm{Y}$, Takei M. Direct effect of dasatinib on signal transduction pathways associated with a rapid mobilization of cytotoxic lymphocytes. Cancer Med. (2016) 5:3223-34. doi: 10.1002/ cam 4.925

54. Zhang B, Li M, McDonald T, Holyoake TL, Moon RT, Campana $\mathrm{D}$, et al. Microenvironmental protection of CML stem and progenitor cells from tyrosine kinase inhibitors through $\mathrm{N}$-cadherin and Wnt-betacatenin signaling. Blood (2013) 121:1824-38. doi: 10.1182/blood-2012-02412890
Conflict of Interest Statement: The authors declare that the research was conducted in the absence of any commercial or financial relationships that could be construed as a potential conflict of interest.

Copyright $\odot 2018$ Damele, Montaldo, Moretta, Vitale and Mingari. This is an openaccess article distributed under the terms of the Creative Commons Attribution License (CC BY). The use, distribution or reproduction in other forums is permitted, provided the original author(s) and the copyright owner(s) are credited and that the original publication in this journal is cited, in accordance with accepted academic practice. No use, distribution or reproduction is permitted which does not comply with these terms. 